Ebba Witt-Brattström

\title{
Nordisk litteratur vid Helsingfors universitet: mångfald och stark utveckling
}

Ämnet Nordisk litteratur fokuserar på svenskspråkig litteratur i Finland och i Sverige, samt dansk, norsk och isländsk litteratur - mot bakgrund av litteraturens utveckling internationellt. Forskningen som bedrivs vid ämnet har en huvudinriktning på finlandssvensk och svensk litteratur, både äldre och yngre, men även dansk och norsk litteratur. 2016 arrangerade Nordisk litteratur den första internationella konferensen om KarlOve Knausgårds Min kamp, och utgav även en konferensvolym (red. Claus Elholm Andersen). Ämnet är traditionellt starkt inom modernismforskningen med tre Södergranforskare (Holger Lillqvist, Ebba Witt-Brattström, Agneta Rahikainen), samt en R.R. Eklundforskare (Martin Welander). 2017 disputerar Eva Kuhlefelt på en avhandling om den unga Hagar Olssons romaner.

Ett forskningsprojekt under ledning av docent Kristina Malmio undersöker senmodern spatialitet i finlandssvensk prosa 1990-2010 (deltagare: Kaisa Kurikka, Hanna Lahdenperä, Julia Tidigs). Under åren 2012-2016 har disputationer ägt rum på R.R. Eklund (Martin Welander), på Agneta Enckell och Ann Jäderlund (Tatjana Brandt), på Sigrid Undset (Giuseppe Caruso), på Åsta Holt (Randi Brendsen), på Karl Ove Knausgård (Claus Elholm Andersen), på det svenskspråkiga 1700-talets rolldikt (Daniela Silén), på Eva Dahlgren (Anna Biström). En avhandling om den unga Hagar Olsson är under granskning, och i stöpsleven finns avhandlingar om Monika Fagerholms Diva (Hanna Lahdenperä), Kjell Espmarks romansvit Glömskan (Inger Hämäläinen), essätraditionen i Finland (Patrik Aaltonen), Henrika Ringbom (Topi Lappalainen), samt receptionen i Sverige av samtida finlandssvensk litteratur (Tomi Riittama). Med andra ord är Nordisk litteratur ett starkt forskningsgenererande ämne med ett livaktigt forskarseminarium där även seniora forskare deltar.

Inom lärargruppen finns i synnerhet forskningskompetens på modernistisk lyrik, litteratursociologi, genusvetenskap, populärlitteratur, genreteori, litterär historiografi och psykoanalytisk litteraturteori. Professor Ebba Witt-Brattström förbereder ett större projekt om autofiktion och självbiografier inom svenskspråkig litteratur. Hon har varit svensk huvudredaktör för flerbandsverket Nordisk kvinnolitteraturhistoria I-2, utgett ett antal vetenskapliga studier, däribland om Moa Martinson (ak.avh 1988), Edith Södergran (1997), Ola Hansson och Laura Marholm (2007), det litterära 1970-talet (2013), samt en mångfald vetenskapliga antologier med andras, men även egna texter, såsom 
Ur könets mörker Etc. (2003), Kulturmannen och andra texter (2016) och Kulturkvinnan och andra texter (2017). Docent Kristina Malmio disputerade 2005 på metafiktiva drag i finlandssvensk och finsk populärlitteratur på 1910- och 1920-talen. Hon har varit redaktör för flera vetenskapliga antologier, senast, tillsammans med Mia Österlund (Åbo Akademi), Novel Districts. Critical Readings of Monika Fagerholm (2016). Docent Hadle Oftedal Andersen disputerade 2005 på avhandlingen Kroppsmodernisme, är drivande i nordiska lyrikmodernismnätverk, och har publicerat ett hundratal vetenskapliga artiklar. Hans senaste bok är Bygdemodernisme. Tarjei vesaas og dei ytste ting (2015).

Ämnet Nordisk litteratur får till hösten en ny dansklektor, då fil dr Claus Elholm Andersen lämnar för en permanent forskartjänst i Berkeley, och en ny isländsk lektor. Vi emotser en förnyelse av såväl undervisnings- som forskningsprofilen! Tilläggas kan att våra lektorer, docenter och professorn i ämnet alla är exceptionellt verksamma inom tredje uppgiften, som folkbildare, författare och som kulturskribenter i hela Norden. 